\title{
Pemanfaatan Khamir Antagonis untuk Memperpanjang Umur Simpan dan Mengendalikan Penyakit Antraknosa Buah Pepaya
}

\author{
Utilization of Yeasts Antagonists to Extend Shelf Life \\ and Control Anthracnose Disease of Papaya Fruit
}

\author{
Mutiara Dwi Lestari ${ }^{1}$, Ketty Suketi2 ${ }^{*}$, Winarso Drajad Widodo ${ }^{2}$, dan Suryo Wiyono \\ ${ }^{1}$ Program Studi Agronomi dan Hortikultura, Sekolah Pascasarjana, Institut Pertanian Bogor \\ ${ }^{2}$ Departemen Agronomi dan Hortikultura, Fakultas Pertanian, Institut Pertanian Bogor \\ (IPB University), Jl. Meranti, Kampus IPB Darmaga, Bogor 16680, Indonesia \\ ${ }^{3}$ Departemen Proteksi Tanaman, Fakultas Pertanian, Institut Pertanian Bogor \\ (IPB University), Jl. Meranti, Kampus IPB Darmaga, Bogor 16680, Indonesia
}

Diterima 14 Agustus 2020/Disetujui 2 November 2020

\begin{abstract}
Papaya is one of the climacteric fruits that has a short shelf life and potential for postharvest anthracnose disease disorders caused by the pathogen Colletotrichum gloeosporioides. The purpose of this study was to investigate the effectiveness of several antagonistic yeast species to extend shelf life and controlling anthracnose disease in postharvest of Callina papaya. This research was conducted at the Papaya field in Kanaga Village, Lebak Regency, Banten from November 2018 to July 2019, and Postharvest Laboratory AGH, IPB University from March to July 2019. The experiment was arranged in a randomized complete block design with the treatment of five types of yeasts, i.e., Cryptococcus albidus $Y$, Aureobasidium pullulans Dmg 30 DEP, Rhodotorula minuta Dmg 16 BEP, Candida tropicalis Lm 13 BE, and Pseudozyma hubeiensis Dmg 18 BEP, a fungicide treatment with active ingredient azoxystrobin as a standard, and without treatment as a control. The results showed that the use of Candida tropicalis, Aureobasidium pullulans, and Cryptococcus albidus extended the shelf life of Callina papaya fruit to 12.6, 12.4, dan 12.2 days, respectively, longer than the control that was only 7 days, and effectively prevented anthracnose disease with suppression rates of $58.33 \%, 54.17 \%$, and $50.00 \%$, respectively, during storage. The use of yeast antagonists did not affect the physical and chemical quality of Callina papaya.
\end{abstract}

Keywords: climacteric fruit, Colletotrichum gloeosporioides, postharvest

\section{ABSTRAK}

Pepaya adalah buah klimakterik yang memiliki umur simpan pendek dan potensi gangguan penyakit antraknosa pada saat tahap pascapanen yang disebabkan oleh patogen Colletotrichum gloeosporioides. Tujuan dari penelitian ini adalah mengkaji keefektifan beberapa spesies khamir antagonis untuk memperpanjang umur simpan dan mengendalikan penyakit antraknosa pada pascapanen buah pepaya Callina. Penelitian ini dilaksanakan di kebun pepaya Desa Kanaga, Kabupaten Lebak, Banten pada November 2018 sampai Juli 2019 dan Laboratorium Pascapanen AGH, IPB pada bulan Maret sampai dengan Juli 2019. Penelitian ini menggunakan rancangan kelompok lengkap teracak dengan perlakuan lima jenis khamir yaitu Cryptococcus albidus Yp, Aureobasidium pullulans Dmg 30 DEP, Rhodotorula minuta Dmg 16 BEP, Candida tropicalis Lm 13 BE, dan Pseudozyma hubeiensis Dmg 18 BEP, dan sebagai pembanding perlakuan fungisida berbahan aktif azoksistrobin serta tanpa perlakuan sebagai kontrol. Hasil penelitian menunjukkan penggunaan khamir Candida tropicalis, Aureobasidium pullulans, dan Cryptococcus albidus dapat memperpanjang umur simpan buah pepaya Callina masing-masing 12.6, 12.4, dan 12.2 hari, lebih lama dibandingkan kontrol yang hanya 7 hari, dan efektif mengendalikan penyakit antraknosa dengan tingkat penekanan secara berturut-turut $58.33 \%, 54.17 \%$, dan 50.00\%, selama penyimpanan. Penggunaan khamir antagonis tidak mempengaruhi mutu fisik dan kimia buah pepaya Callina.

Kata kunci: buah klimakterik, Colletotrichum gloeosporioides, pascapanen

\footnotetext{
* Penulis untuk korespondensi. e-mail: kettysuketi.ipb@gmail.com
} 


\section{PENDAHULUAN}

Produksi pepaya (Carica papaya L.) di Indonesia mengalami fluktuasi dari tahun 2011 sampai dengan 2018. Pepaya termasuk dalam 8 besar produksi buah nasional (Badan Pusat Statistik, 2018). Permasalahan utama buah pepaya yaitu memiliki umur simpan pendek dan serangan penyakit antraknosa yang disebabkan oleh Colletotrichum gloeosporioides (Wiyono dan Manuwoto, 2008). Pengembangan pepaya tanpa disertai dengan penanganan pascapanen yang baik akan menyebabkan kehilangan hasil saat pascapanen yang tinggi. Kehilangan pascapanen terbesar disebabkan oleh penyakit antraknosa $(62 \%)$ dan karena buah lewat matang (42\%) (Suyanti, 2011).

Penelitian pascapanen pepaya sebelumnya untuk memperpanjang masa simpan buah, belum menunjukkan hasil yang memuaskan. Penggunaan kitosan $0.25 \%$ tidak mampu menghambat pertumbuhan C. gloeosporoides pada pepaya Callina (Hamdayanty et al., 2012). Penggunaan oksidan etilen $\left(10 \% \mathrm{KMnO}_{4}\right) 0 \mathrm{~g}$ (kontrol), $15 \mathrm{~g}, 30 \mathrm{~g}$, dan $45 \mathrm{~g}$ tidak dapat memperpanjang umur simpan buah pepaya Callina. Hal ini diduga karena umur buah yang digunakan berbeda. Saat pelaksanaan tagging buah, buah ditandai berdasarkan perkiraan warna sehingga memungkinkan adanya umur buah yang berbeda meskipun warna buah sama (Pratiwi et al. 2013). Pelapisan lilin lebah pada buah menyebabkan buah rusak setelah disimpan selama 11 hari dan warna kulit baru mencapai skala 5 (Mukdisari et al., 2016). Perlakuan hipoklorit pada buah pepaya hanya bertahan sampai skala 4 dan memiliki penampilan buah yang kurang menarik dengan masa simpan 8.67 HSP (Suketi et al., 2017).

Pencegahan penyakit antraknosa pada buah pascapanen umumnya dilakukan menggunakan fungisida. Hasil percobaan Yunita et al. (2018) menunjukkan bahwa pencucian buah dengan bahan pencuci yang ditambah fungisida berbahan aktif azoksistrobin dan difenokonazol atau khamir antagonis $C r$. albidus efektif untuk meningkatkan kualitas visual mangga, mencegah dan menekan serangan penyakit antraknosa, dan mampu meningkatkan umur simpan mangga Arumanis dan Gedong. Penggunaan fungisida sintetik secara berlebihan dapat meninggalkan residu pada produk pascapanen. Salah satu alternatif pengendalian yang dapat digunakan untuk mengatasi masalah tersebut adalah pengendalian hayati menggunakan khamir antagonis. Hasil percobaan Zheng et al. (2013) menunjukkan bahwa mikroorganisme antagonis mampu menghambat aktivitas cendawan antraknosa hingga $98.75 \%$ sehingga sangat efektif digunakan untuk menjaga kualitas mangga selama periode penyimpanan pascapanen, distribusi, dan pemasaran.

Khamir telah digunakan sebagai agens hayati untuk mengendalikan penyakit buah pascapanen dan meningkatkan umur simpan dalam beberapa tahun terakhir. Perlakuan khamir Aureobasidium pullulans dan Rhodotorula mucilaginosa yang diisolasi dari buah pir dapat menekan infeksi Penicillium expansum dan mengurangi insidensi penyakit hingga 33\% (Robiglio et al., 2011). Khamir Cryptococcus albidus var aerius IPB1, Cryptococcus albidus var aerius IPB2, dan Candida edax masing-masing dapat mengendalikan Colletotrichum acutatum pada cabai sebesar 57.5, 52.5, dan 62.5\% (Wilia et al., 2012). Cryptococcus albidus var. aerius WSW1 adalah isolat khamir antagonis paling efektif terhadap Botryodiplodia theobromae pada buah mangga dengan tingkat penekanan $70.83 \%$ (Sugiprihatini et al., 2011). Penggunaan khamir $A$. pullulans dan $C a$. tropicalis efektif dalam mengendalikan penyakit antraknosa dan meningkatkan umur simpan buah mangga mencapai $90 \%$ dan $106 \%$ pada suhu ruang $25^{\circ} \mathrm{C}$ (Jumawati et al., 2018).

Agens biokontrol memiliki 4 mekanisme utama dalam mengendalikan penyakit yaitu kompetisi nutrisi dan ruang, hiperparasitisme, antibiosis, dan induksi resistensi (Sharma et al., 2009). Pengendalian hayati menggunakan khamir antagonis merupakan salah satu pilihan pengendalian penyakit antraknosa buah pepaya Callina yang menjanjikan karena mudah didapat, dapat tumbuh cepat dengan menghasilkan sel dalam jumlah besar, tidak menghasilkan spora alergik atau mikotoksin, tidak menimbulkan residu berbahaya pada buah pepaya jika dikosumsi, dan aman terhadap lingkungan. Oleh karena itu, pemanfaatan khamir antagonis sebagai pengendalian hayati penyakit antraknosa buah pepaya Callina berpotensi untuk pengendalian. Penelitian ini bertujuan mengkaji keefektifan beberapa spesies khamir antagonis untuk memperpanjang umur simpan dan mengendalikan penyakit antraknosa buah pepaya Callina.

\section{BAHAN DAN METODE}

Penelitian dilakukan di kebun pepaya Desa Kanaga, Kabupaten Lebak, Banten pada November 2018 hingga Juli 2019. Analisis kualitas fisik dan kimia buah dilakukan di Laboratorium Pascapanen, Departemen Agronomi dan Hortikultura, Fakultas Pertanian, IPB. Penyiapan buah diawali dengan penandaan bunga hermafrodit dari populasi 200 tanaman yang berumur 4 bulan. Isolat khamir $C r$. albidus Yp, A. pullulans Dmg 30 DEP, R. minuta Dmg 16 BEP, Ca. tropicalis Lm 13 BE, dan P. hubeiensis Dmg 18 BEP diperoleh dari stok kultur koleksi Laboratorium Klinik Tanaman, Departemen Proteksi Tanaman, IPB. Satu isolat khamir koleksi, yaitu $C r$. albidus berasal dari tanaman bawang merah. Empat isolat khamir, yaitu A. pullulans, $R$. minuta, Ca. tropicalis, dan P. hubeiensis dari tanaman cabai.

Percobaan ini dilakukan menggunakan rancangan kelompok lengkap teracak (RKLT) dengan faktor tunggal yaitu jenis khamir. Jenis khamir yang digunakan pada setiap percobaan yaitu Cryptococcus albidus Yp, Aureobasidium pullulans Dmg 30 DEP, Rhodotorula minuta Dmg 16 BEP, Candida tropicalis Lm $13 \mathrm{BE}$, dan Pseudozyma hubeiensis Dmg 18 BEP, dan sebagai pembanding perlakuan fungisida berbahan aktif azoksistrobin serta tanpa perlakuan sebagai kontrol. Setiap perlakuan terdiri atas 5 ulangan sehingga menghasilkan 35 satuan percobaan. Setiap satuan percobaan terdiri atas 5 buah sampel sehingga buah pepaya yang digunakan berjumlah 175 buah. 
Buah pepaya yang akan diuji, dipanen setelah mencapai akumulasi satuan panas $2,200.0{ }^{\circ} \mathrm{C}$ hari dengan suhu dasar $10{ }^{\circ} \mathrm{C}$ pada Maret 2019 dan sortasi berdasarkan keseragaman bentuk, ukuran (bobot 1.1-1.5 kg), dan total kerusakan maksimum 15\% dari luas permukaan kulit dan tidak mempengaruhi daging buah. Larutan bahan pencelup khamir merupakan campuran dari isolat khamir yang ditumbuhkan dalam $10 \mathrm{~mL}$ media cair PDB dengan konsentrasi $10^{7} \mathrm{sel}$ $\mathrm{mL}^{-1}$ dihitung menggunakan hemasitometer Neubauerimproved dan ditambah Tween $20(0.1 \%)$ (Fitriati et al., 2013). Suspensi ini kemudian dilarutkan dalam 10 L air. Buah pepaya dicelupkan dalam larutan khamir selama 5 menit kemudian diangkat dan dikeringanginkan selama 5 menit (Sutopo et al., 2016; Yunita et al., 2018).

Selama 13 hari periode penyimpanan dari skala 1 sampai skala 7 dilakukan perhitungan umur simpan dan perkembangan penyakit antraknosa (Insidensi dan keparahan penyakit antraknosa). Saat mencapai skala 7, ditetapkan sebagai umur simpan buah dan dilakukan analisis kualitas fisik dan kimia buah mengacu Taris et al. (2015) dan Farida (2017). Insidensi penyakit ditentukan dengan menghitung persentase buah uji yang sakit terhadap jumlah buah uji total. Buah uji yang sakit pada buah pepaya dicirikan dengan gejala awal antraknosa berupa bercak konsentrik berwarna abu-abu atau kehitaman dengan titik-titik oranye pada permukaannya. Keparahan penyakit dilakukan dengan cara skoring (Hamdayanty et al., 2012). Pengukuran kekerasan buah dilakukan pada bagian pangkal, tengah, dan ujung buah menggunakan alat penetrometer. Padatan terlarut total (PTT) diukur dengan hand refractometer.

Data hasil pengamatan dianalisis menggunakan analisis ragam pada taraf nyata $5 \%$ dan perlakuan yang berpengaruh nyata dilanjutkan dengan uji Beda Nyata Jujur (BNJ) dengan menggunakan Software SAS (Statistical Analysis System) versi 9.4.

\section{HASIL DAN PEMBAHASAN}

\section{Umur Simpan dan Kualitas Fisik}

Perlakuan khamir antagonis dapat meningkatkan umur simpan dan tidak mempengaruhi kualitas fisik buah pepaya (Tabel 1). Umur simpan buah dengan perlakuan khamir tertinggi secara berurutan Ca. tropicalis (12.6 hari) dengan peningkatan sebesar $80 \%$, A pullulans (12.4 hari) dengan peningkatan sebesar $77.1 \%$, dan $C$ r. albidus $(12.2$ hari) dengan peningkatan sebesar $74.3 \%$ dibandingkan dengan buah pepaya tanpa perlakuan. Sebagai pembanding perlakuan khamir antagonis yaitu perlakuan fungisida (12.6 hari) dengan peningkatan sebesar 80\% (Tabel 1). Tidak ada perbedaan umur simpan dari buah dengan perlakuan khamir (Ca. tropicalis, A. pullulans, dan Cr. albidus) dan perlakuan fungisida bahan aktif azoksistrobin (Tabel 1). Hal ini diduga karena mekanisme yang dimiliki khamir Ca. tropicalis dan A. pullulans yang mampu menghasilkan enzim ACC deaminase dan fungisida bahan aktif azoksistrobin yang dapat menghambat respirasi cendawan pada mitokondria, sehingga mampu menekan serangan penyakit antraknosa dan meningkatkan umur simpan buah pepaya. Hasil penelitian ini sejalan dengan hasil penelitian Yunita et al. (2018) melaporkan bahwa perlakuan bahan pencuci yang ditambah dengan fungisida bahan aktif azoksistrobin atau khamir antagonis Cr. albidus menyebabkan kondisi pertumbuhan kurang menguntungkan bagi patogen untuk tumbuh dan berkembang pada kondisi penyimpanan. Selain itu penggunaan fungisida mengandung bahan aktifazoksistrobin memiliki efektivitas sangat baik dalam mengatasi serangan cendawan dengan cara mencegah terjadinya produksi spora cendawan dan menghambat metabolisme jamur. Fungisida bahan aktif azoksistrobin mampu untuk meningkatkan kualitas visual mangga, mencegah dan menekan serangan penyakit antraknosa, dan mampu meningkatkan umur simpan mangga Arumanis dan Gedong hingga 36 HSP.

Tabel 1 menunjukkan hasil bahwa buah pepaya Callina tanpa perlakuan memiliki umur simpan paling pendek yaitu 7 hari. Hasil penelitian ini sejalan dengan hasil penelitian Jumawati et al. (2018) umur simpan mangga dengan perlakuan $\mathrm{Ca}$. tropicalis meningkat $106 \%$ bila dibandingkan dengan tanpa perlakuan. Peningkatan umur simpan buah pepaya terjadi karena mekanisme yang dimiliki oleh khamir antagonis sehingga buah terhindar dari penyakit antraknosa yang sering menyerang pepaya. Hasil penelitian Chan dan Tian (2005) Cr. albidus memiliki kemampuan hiperparasitisme yang cukup kuat terhadap hifa

Tabel 1. Pengaruh khamir antagonis terhadap umur simpan dan kualitas fisik buah pepaya selama penyimpanan

\begin{tabular}{|c|c|c|c|c|c|}
\hline Perlakuan & $\begin{array}{l}\text { Umur simpan } \\
\text { (hari) }\end{array}$ & $\begin{array}{c}\text { Peningkatan } \\
\text { umur simpan } \\
(\%)\end{array}$ & $\begin{array}{c}\text { Susut bobot } \\
(\%)\end{array}$ & $\begin{array}{c}\text { Kekerasan } \\
\text { kulit buah } \\
\left(\mathrm{mm} \mathrm{g}^{-1}\right) \text { detik }^{-1}\end{array}$ & $\begin{array}{c}\text { Kekerasan } \\
\text { daging buah } \\
\left(\mathrm{mm} \mathrm{g}^{-1}\right) \text { detik }^{-1}\end{array}$ \\
\hline Tanpa perlakuan & $7.0 \mathrm{c}$ & 0.0 & 12.1 & 0.1 & 0.2 \\
\hline Cr. albidus (Yp) & $12.2 \mathrm{a}$ & 74.3 & 10.8 & 0.1 & 0.2 \\
\hline Ca. tropicalis (Lm $13 \mathrm{BE})$ & $12.6 \mathrm{a}$ & 80.0 & 10.6 & 0.1 & 0.2 \\
\hline A. pullulans (Dmg 30 DEP) & $12.4 \mathrm{a}$ & 77.1 & 10.6 & 0.1 & 0.2 \\
\hline P. hubeiensis (Dmg 18 BEP) & $9.6 b$ & 37.1 & 11.6 & 0.1 & 0.2 \\
\hline R. minuta (Dmg 16 BEP) & $8.8 \mathrm{~b}$ & 25.7 & 11.7 & 0.1 & 0.2 \\
\hline Fungisida & $12.6 \mathrm{a}$ & 80.0 & 10.5 & 0.1 & 0.2 \\
\hline
\end{tabular}

Keterangan: Angka-angka yang diikuti huruf yang sama pada kolom yang sama menunjukkan nilai yang tidak berbeda nyata berdasarkan uji lanjut BNJ pada taraf 5\% 
Monilinia fructicola, Penicillium expansum, dan Rhizopus stolonifer pada buah apel. Menurut Hartati et al. (2019) kedua khamir tersebut baik $A$. pullulans dan Ca. tropicalis selain memiliki mekanisme pengendalian hiperparasitisme yang mampu mendegradasi dinding sel hifa sehingga menyebabkan hancurnya hifa Colletotrichum acutatum, juga memiliki aktivitas enzim ACC deaminase yang dapat memperpanjang umur simpan pada cabai dengan cara menekan produksi etilen. Menurut Paramita (2010) buah mangga gedong gincu yang mengalami memar atau luka mengakibatkan laju respirasi dan produksi etilen meningkat. Menurut Workneh et al. (2012) umur simpan pepaya dapat dipengaruhi oleh faktor-faktor respirasi, struktur biologis, produksi etilen, transpirasi, perubahan komposisi kimia, proses perkembangan, dan gangguan fisiologis.

Semua perlakuan tidak mempengaruhi kualitas fisik buah pepaya Callina selama penyimpanan. Buah pepaya tetap lunak sama seperti buah tanpa perlakuan. Semakin lama penyimpanan buah pepaya semakin lunak (Tabel 1). Hasil penelitian ini sejalan dengan hasil penelitian Farida (2017) perbedaan jumlah satuan panas saat panen pada skala warna 7 pada buah pepaya Callina tidak mempengaruhi susut bobot berkisar antara 9.87 sampai $12.85 \%$, kekerasan kulit buah berkisar antara 0.15 sampai $0.17\left(\mathrm{~mm} \mathrm{~g}^{-1}\right)$ detik $^{-1}$, dan kekerasan daging buah berkisar antara 0.23 sampai 0.26 $\left(\mathrm{mm} \mathrm{g}^{-1}\right) \operatorname{detik}^{-1}$.

Perlakuan khamir antagonis buah pepaya Callina tidak mempengaruhi susut bobot selama penyimpanan. Nilai susut bobot buah pepaya Callina berkisar antara 10.5 sampai $12.1 \%$ (Tabel 1). Hasil penelitian ini sejalan dengan hasil penelitian Jumawati et al. (2018) melaporkan bahwa pencelupan buah mangga pada larutan khamir tidak mempengaruhi susut bobot buah pada penyimpanan suhu ruang. Susut bobot buah mangga mengalami peningkatan seiring dengan bertambahnya umur simpan buah mangga. Menurut Andriani et al. (2018) susut bobot terjadi karena terjadinya kehilangan air dalam buah yang diakibatkan oleh proses penguapan dan kehilangan karbon selama respirasi. Tomat yang telah dipanen tetap hidup dan melakukan proses respirasi sehingga susut bobot akibat respirasi tidak dapat dihindari. Menurut Tarigan et al. (2016) buah yang tergolong klimaterik seperti tomat, respirasinya meningkat saat penyimpanan awal dan menurun seiring dengan lama simpan. Menurut Arifiya et al. (2015) pepaya merupakan buah klimakterik yang masih dapat mencapai puncak respirasi meski telah dipanen, selain itu buah juga masih melakukan proses metabolisme yang menunjukkan proses kehidupan masih berlangsung.

Nilai kekerasan kulit dan nilai kekerasan daging buah untuk semua perlakuan, masing-masing $0.1\left(\mathrm{~mm} \mathrm{~g}^{-1}\right) \operatorname{detik}^{-1}$ dan $0.2\left(\mathrm{~mm} \mathrm{~g}^{-1}\right) \operatorname{detik}^{-1}$ (Tabel 1), tidak menunjukkan perbedaan yang signifikan pada buah pepaya Callina (Tabel 1). Semakin tinggi nilai kekerasan buah yang diperoleh maka semakin lunak kulit dan daging buah. Menurut Sancho et al. (2010) kekerasan buah berkorelasi positif terhadap aktivitas dua enzim utama yaitu poligalakturonase (PG) dan pektin metil esterase (PME), yang dapat mendegradasi dinding sel dan menyebabkan buah menjadi lunak selama proses kematangan buah. Hasil penelitian ini sejalan dengan hasil penelitian Jumawati et al. (2018) yaitu perlakuan khamir antagonis tidak mempengaruhi kekerasan buah mangga pada penyimpanan suhu ruang $\left(25^{\circ} \mathrm{C}\right)$. Hal ini diduga akibat etilen tetap terbentuk walaupun prekursornya sudah digunakan untuk kebutuhan nutrisi khamir yang menghasil ACC deaminase.

\section{Kualitas Kimia Buah Pepaya Callina}

Semua perlakuan tidak mempengaruhi kandungan PTT, ATT, rasio PTT/ATT, dan Vitamin C buah pepaya Callina. Kualitas kimia pada buah pepaya Callina tanpa perlakuan memiliki kandungan PTT 10.90 obrix, ATT $0.24 \%$, rasio PTT/ATT 46.29, dan vitamin C $67.72 \mathrm{mg}$ (Tabel 2). Menurut Hartati et al. (2019) aktivitas enzim ACC deaminase pada khamir $C a$. tropicalis, A. pullulans, dan $R$. minuta dapat mendegradasi ACC. Degradasi yang terus-menerus dapat menurunkan etilen. Penurunan produksi etilen akibat dari degradasi ACC menjadi $\alpha$-ketobutirat dan ammonia yang disebabkan oleh enzim ACC deaminase yang dihasilkan oleh khamir antagonis, tidak mampu menurunkan proses biokimia.

Nilai komposisi kimia hasil penelitian ini sejalan dengan hasil penelitian Mukdisari et al. (2016) perlakuan pelapisan kitosan dan lilin lebah tidak mempengaruhi mutu

Tabel 2. Pengaruh khamir antagonis terhadap kualitas kimia buah pepaya selama penyimpanan

\begin{tabular}{lcccc}
\hline Perlakuan & $\begin{array}{c}\text { PTT } \\
\left({ }^{\circ} \text { Brix }\right)\end{array}$ & $\begin{array}{c}\text { ATT } \\
(\%)\end{array}$ & $\begin{array}{c}\text { Rasio } \\
\text { PTT/ATT }\end{array}$ & $\begin{array}{c}\text { Vitamin C } \\
\left(\mathrm{mg} \mathrm{100}^{-1}\right)\end{array}$ \\
\hline Tanpa perlakuan & 10.90 & 0.24 & 46.29 & 67.72 \\
Cr. albidus (Yp) & 11.33 & 0.20 & 57.62 & 70.17 \\
Ca. tropicalis (Lm 13 BE) & 11.67 & 0.19 & 63.43 & 74.62 \\
A. pullulans (Dmg 30 DEP) & 11.53 & 0.19 & 60.83 & 72.93 \\
P. hubeiensis (Dmg 18 BEP) & 11.07 & 0.22 & 51.11 & 69.37 \\
R. minuta (Dmg 16 BEP) & 11.02 & 0.23 & 48.22 & 68.9 \\
Fungisida & 11.73 & 0.18 & 65.92 & 74.20 \\
\hline
\end{tabular}

Keterangan: Angka-angka yang diikuti huruf yang sama pada kolom yang sama menunjukkan nilai yang tidak berbeda nyata berdasarkan uji lanjut BNJ pada taraf 5\%; PTT = padatan terlarut total; $\mathrm{ATT}=$ asam terlarut total 
kimia buah pepaya Callina. Buah pepaya Callina tanpa perlakuan memiliki kandungan PTT 10.61 obrix, ATT $0.81 \%$, rasio PTT/ATT 13.19, dan vitamin C $61.01 \mathrm{mg}$. Menurut Suketi et al. (2010) nilai PTT buah pepaya semakin meningkat dengan bertambahnya stadia kematangan buah. Sancho et al. (2010) menyatakan bahwa selama proses pematangan nilai PTT cenderung meningkat sedangkan ATT cenderung menurun. Menurut Tirkey et al. (2014) buah pepaya yang mengalami pembusukan dan kerusakan menyebabkan kandungan gula di dalamnya akan terdegradasi menjadi asam, sehingga nilai PTT mengalami penurunan dari 8.5 menjadi $7^{\circ}$ brix. Jumawati et al. (2018) melaporkan bahwa rasio PTT/ATT yang tinggi menunjukkan bahwa rasa manis lebih dominan dibandingkan dengan rasa asam yang dimiliki buah mangga. Menurut Mladenoska (2012) menyatakan pelapisan berfungsi sebagai penghalang yang baik untuk mencegah kontak antara oksigen di atmosfer dan permukaan buah, sehingga dapat menghambat proses oksidasi asam askorbat. Buah aprikot yang diberikan bahan pelapis memiliki kandungan vitamin $\mathrm{C}$ yang lebih tinggi dari pada buah tanpa perlakuan. Menurut Serry (2011) terjadinya degradasi dinding sel selama proses pematangan dapat memberikan substrat untuk sintesis asam askorbat pada pepaya Solo.

\section{Insidensi dan Keparahan Penyakit Antraknosa}

Semua perlakuan khamir antagonis menunjukkan kemampuan penekanan penyakit secara nyata dibandingkan dengan tanpa perlakuan. Perlakuan khamir Ca. tropicalis, $\mathrm{A}$. pullulans, dan $C r$ r albidus menunjukkan insidensi penyakit lebih rendah dengan tingkat penekanan secara berturutturut $58.33 \%, 54.17 \%$, dan $50.00 \%$ dibandingkan dengan tanpa perlakuan dan tidak berbeda nyata dengan perlakuan fungisida bahan aktif azoksistrobin (Tabel 3). Sesuai dengan hasil penelitian Wilia et al. (2012) melaporkan bahwa khamir Cryptococcus terreus, Candida edax, dan Cryptococcus albidus var aerius IPB 1 insidensi penyakitnya tidak berbeda nyata dengan perlakuan mankozeb. Kemampuan khamir dalam menekan insidensi penyakit diduga karena khamir mampu menghasilkan enzim yang berpotensi menghambat, menekan, dan mampu merangsang beberapa jenis respon pertahanan inang. Enzim tersebut mampu mendegradasi dinding sel patogen.

Tabel 4 menunjukkan hasil bahwa buah pepaya dengan perlakuan khamir Cr. albidus, Ca.tropicalis, dan A. pullulans menunjukkan nilai persentase keparahan penyakit terendah, terlihat pada skala kematangan 1 sampai 2 tidak terinfeksi penyakit antraknosa, dan mulai terjadi serangan penyakit antraknosa pada skala kematangan 3 sampai 7. Perlakuan khamir Ca. tropicalis, A. pullulans, dan Cr. albidus efektif menekan serangan penyakit antraknosa buah pepaya selama penyimpanan yang terlihat pada skala kematangan 7 secara berturut-turut dengan persentase sebesar 30.00\%, 36.00\%, dan 40.00\% (Tabel 4). Menurut Rangkuti et al. (2017) faktor pertama yang mempengaruhi perkembangan infeksi ini yaitu apabila buah pepaya hampir matang, patogen mudah untuk mendegradasi lapisan bagian epidermis pada kulit buah, dan faktor yang kedua adalah substrat dengan kadar gula yang cukup akan mendukung bagi patogen untuk melakukan infeksi dan kolonisasi. Hartati et al. (2019) melaporkan bahwa mekanisme pengendalian oleh khamir $\mathrm{Ca}$. tropicalis dan A. pullulans terjadi melalui produksi ACC deaminase. Penggunaan khamir antagonis ini dapat dimanfaatkan dalam menunda pemasakan buah dan menghindari infeksi Colletotrichum acutatum pada buah cabai.

Mekanisme yang dimiliki khamir antagonis untuk mengendalikan penyakit antraknosa pada buah pepaya Callina yaitu kompetisi nutrisi dan ruang, hiperparasitisme, dan antibiosis serta lisis. Menurut Alsoufi dan Aziz (2017) penggunaan khamir $A$. pullulans dapat menghambat pertumbuhan mikroorganisme penyebab busuk buahbuahan dan efektif mengurangi susut bobot buah selama pemasaran sehingga mampu memperpanjang umur simpan buah. Francesco et al. (2014) melaporkan bahwa khamir $A$. pullulans efektif dalam mengendalikan penyakit pascapanen pada beberapa komoditas hortikultura.

Penurunan serangan penyakit antraknosa pada perlakuan khamir antagonis (Tabel 4), menghasilkan kualitas yang baik dan relatif tidak mempengaruhi kualitas fisik dan kimia, sehingga dapat meningkatkan umur simpan buah pepaya Callina selama penyimpanan. Menurut Hartati et al.

Tabel 3. Pengaruh perlakuan khamir antagonis terhadap insidensi penyakit antraknosa buah pepaya selama penyimpanan

\begin{tabular}{lcc}
\hline Perlakuan & $\begin{array}{c}\text { Insidensi penyakit antraknosa (\%) } \\
\text { selama penyimpanan }\end{array}$ & $\begin{array}{c}\text { Penekanan } \\
(\%)\end{array}$ \\
\hline Tanpa perlakuan & $96.00 \pm 8.94 \mathrm{a}$ & 0.00 \\
Cr. albidus (Yp) & $48.00 \pm 26.83 \mathrm{~b}$ & 50.00 \\
Ca. tropicalis (Lm 13 BE) & $40.00 \pm 20.00 \mathrm{~b}$ & 58.33 \\
A. pullulans (Dmg 30 DEP) & $44.00 \pm 29.66 \mathrm{~b}$ & 54.17 \\
P. hubeiensis (Dmg 18 BEP) & $92.00 \pm 10.95 \mathrm{a}$ & 4.17 \\
R. minuta (Dmg 16 BEP) & $92.00 \pm 10.95 \mathrm{a}$ & 4.17 \\
Fungisida & $32.00 \pm 17.89 \mathrm{~b}$ & 66.67 \\
\hline
\end{tabular}

Keterangan: Angka-angka yang diikuti huruf yang sama pada kolom yang sama menunjukkan nilai yang tidak berbeda nyata berdasarkan uji lanjut BNJ pada taraf 5\% 
Tabel 4. Pengaruh khamir antagonis terhadap perkembangan penyakit antraknosa buah pepaya selama penyimpanan

\begin{tabular}{lccccccc}
\hline \multirow{2}{*}{ Perlakuan } & \multicolumn{7}{c}{ Keparahan penyakit (\%) pada skala kematangan buah } \\
\cline { 2 - 7 } & 1 & 2 & 3 & 4 & 5 & 6 & 7 \\
\hline Tanpa perlakuan & 0.00 & 0.00 & 0.00 & 8.00 & $40.00 \mathrm{a}$ & $64.00 \mathrm{a}$ & $88.00 \mathrm{a}$ \\
Cr. albidus (Yp) & 0.00 & 0.00 & 0.00 & 3.00 & $12.00 \mathrm{bc}$ & $29.00 \mathrm{bcd}$ & $40.00 \mathrm{~b}$ \\
Ca. tropicalis (Lm 13 BE) & 0.00 & 0.00 & 0.00 & 1.00 & $8.00 \mathrm{bc}$ & $21.20 \mathrm{~cd}$ & $30.00 \mathrm{~b}$ \\
A. pullulans (Dmg 30 DEP) & 0.00 & 0.00 & 5.00 & 7.00 & $11.00 \mathrm{bc}$ & $23.40 \mathrm{~d}$ & $36.00 \mathrm{~b}$ \\
P. hubeiensis (Dmg 18 BEP) & 0.00 & 0.00 & 8.00 & 16.00 & $24.00 \mathrm{ab}$ & $50.00 \mathrm{ab}$ & $77.00 \mathrm{a}$ \\
R. minuta (Dmg 16 BEP) & 0.00 & 0.00 & 0.00 & 3.00 & $15.00 \mathrm{~b}$ & $46.80 \mathrm{abc}$ & $80.00 \mathrm{a}$ \\
Fungisida & 0.00 & 0.00 & 1.00 & 1.00 & $1.00 \mathrm{c}$ & $11.40 \mathrm{~d}$ & $27.00 \mathrm{~b}$ \\
\hline
\end{tabular}

Keterangan: Angka-angka yang diikuti huruf yang sama pada kolom yang sama menunjukkan nilai yang tidak berbeda nyata berdasarkan uji lanjut BNJ pada taraf $5 \%$

(2019) khamir antagonis ini berpotensi untuk menggantikan fungisida sintetik, karena tingkat pengendalian oleh khamir (99.14\%) terhadap penyebab Colletotrichum acutatum lebih besar dibandingkan dengan mankozeb $(80 \%)$.

\section{KESIMPULAN}

Penggunaan khamir Candida tropicalis, Aureobasidium pullulans, dan Cryptococcus albidus efektif dalam mengendalikan penyakit antraknosa pada buah pepaya Callina dengan tingkat penekanan secara berturutturut $58.33 \%, 54.17 \%$, dan $50.00 \%$ selama penyimpanan. Aplikasi khamir Candida tropicalis, Aureobasidium pullulans, dan Cryptococcus albidus dapat memperpanjang umur simpan buah pepaya Callina masing-masing 12.6, 12.4, dan 12.2 hari lebih lama dibandingkan kontrol yang hanya 7 hari. Penggunaan khamir antagonis tidak mempengaruhi mutu fisik dan kimia buah pepaya Callina.

\section{DAFTAR PUSTAKA}

Alsoufi, M.A., R.A. Aziz. 2017. Extending shelf life of fruits by using some microorganisms biological products. Int. J. Mol. Biol. 2:141-144.

Andriani, E.S., Nurwantoto, A. Hintono. 2018. Perubahan fisik tomat selama penyimpanan pada suhu ruang akibat pelapisan dengan agar-agar. J. Teknol. Pangan 2:176-182.

Arifiya, N., Y.A. Purwanto, I.W. Budiastra. 2015. Analisis perubahan kualitas pascapanen pepaya varietas IPB9 pada umur petik yang berbeda. J. Keteknikan Pertanian 3:41-48.

Badan Pusat Statistik. 2018. Statistik Tanaman Buahbuahan dan Sayuran Tahunan Indonesia. http://www. bps.go.id [12 April 2020].
Chan, Z., S. Tian. 2005. Interaction of antagonistic yeasts against postharvest pathogens of apple fruit and possible mode of action. Postharvest. Biol. Tec. $36: 215-223$.

Farida, R. 2017. Pengaruh Jumlah Satuan Panas terhadap Kematangan Pascapanen dan Viabilitas Benih Pepaya Callina. Tesis. Sekolah Pascasarjana. Institut Pertanian Bogor. Bogor.

Fitriati, Y., S. Wiyono, I.O. Sumarauw. 2013. Khamir antagonis untuk pengendalian penyakit antraknosa pada buah avokad selama penyimpanan. J. Fitopatologi Indonesia 9:153-159.

Francesco, A.D., L. Ugolini, L. Lazzeri, M. Mari. 2014. Production of volatile organic compound by Aureobasidium pullulans as a potential mechanism of action against postharvest fruit pathogens. Biol. Control. 81:8-14.

Hamdayanty, R. Yunita, N.N. Amin, T.A. Damayanti. 2012. Pemanfaatankitosanuntuk mengendalikan antraknosa pada pepaya (Colletotrichum gloeosporioide) dan meningkatkan daya simpan buah. J. Fitopatologi Indonesia 8:97-102.

Hartati, S., S. Wiyono, S.H. Hidayat, M.S. Sinaga. 2019. Antagonism mechanism of epiphytic yeast against anthracnose pathogen (Colletotrichum acutatum) on chilli. J. Perlindungan Tanaman Indonesia 23:47-53.

Jumawati, R., R. Poerwanto, S. Wiyono, K. Suketi. 2018. Pengaruh beberapa khamir antagonis terhadap penyakit antraknosa dan umur simpan pada buah mangga. J. Fitopatologi Indonesia 4:153-158. 
Mladenoska, I. 2012. The potential application of novel beeswax edible coatings containing coconut oil in the minimal processing of fruits. Adv. Technol. $1: 26-34$.

Mukdisari, Y., K. Suketi, W.D. Widodo. 2016. Fruit coating with chitosan and beeswax to increase papaya shelf life. J. Trop. Crop Sci. 3:93-98.

Paramita, O. 2010. Pengaruh memar terhadap perubahan pola respirasi, produksi etilen dan jaringan buah mangga (Mangifera indica L.) var. gedong gincu pada berbagai suhu penyimpanan. J. Kompetensi Teknik 2:29-37.

Pratiwi, H.E., K. Suketi, W.D. Widodo. 2013. Aplikasi kalium permanganat sebagai oksidan etilen dalam penyimpanan buah pepaya IPB callina. hal. 44-50. Dalam J.G. Kartika, W.B. Suwarno, S.W. Ardhie, C.P.E.Sanura,F.N.Fitriana(Eds.).MembangunSistem baru Agribisnis Hortikultura Indonesia pada Era Pasar Global. Prosiding Seminar Ilmiah Perhimpunan Hortikultura Indonesia (Perhorti). Bogor 9 Oktober 2013.

Rangkuti, E.E., S. Wiyono, Widodo. 2017. Identifikasi Colletotrichum spp. asal tanaman pepaya. J. Fitopatologi Indonesia 13:175-183.

Robiglio, A., M.C. Sosa, M.C. Lutz, C.A. Lopes, M.P. Sangorr'n. 2011. Yeast biocontrol of fungal spoilage of pears stored at low temperature. Int. J. Food Microbiol. 147:211-216.

Sancho, L.E.G.G., E.M. Yahia, M.A. Martinez-Tellez, G.A. Gonzalez-Aguilar. 2010. Effect of maturity stage of papaya maradol on physiological and biochemical parameters. Am. J. Agri. Biol. Sci. 5:194-203.

Serry, N.K.H. 2011. Postharvest handling of Solo papaya fruits harvested at different maturity stages. AmericanEurasian. J. Agric. Environ Sci. 11:205-210.

Sharma, R.R., D. Singh, R. Singh. 2009. Biological control of postharvest diseases of fruits and vegetables by microbial antagonists: A review. Biol. Control. 50:205-221.

Sugiprihatini, D., S. Wiyono, Widodo. 2011. Selection of yeasts antagonists as biocontrol agent of mango fruit rot caused by (Botryodiplodia theobromae). Microbiology. 5:154-159.

Suketi, K., R. Poerwanto, S. Sujiprihati, Sobir, W.D. Widodo. 2010. Karakter fisik dan kimia buah pepaya pada stadia kematangan berbeda. J. Agron. Indonesia $38: 17-26$.
Suketi, K., W.D. Widodo, A. Aziz. 2017. Asap cair sebagai disinfektan untuk peningkatan daya simpan buah pepaya Callina. hal. 273. Dalam M.R. Suhartanto, S.I. Aisyah, E.R. Palupi, A. Nindita (Eds.). Inovasi untuk Mempercepat Peningkatan Daya Saing Hortikultura. Prosiding Seminar Nasional dan Kongres Perhimpunan Hortikultura Indonesia (Perhorti) 2017. Bogor 11-12 Oktober 2017.

Sutopo, A., R. Poerwanto, S. Wiyono. 2016. Keefektifan bahan pencuci dan pencegah penyakit terhadap kualitas buah mangga cv. Gedong gincu dan Arumanis. J. Hort. 27:253-260.

Suyanti. 2011. Peran teknologi pascapanen untuk meningkatkan mutu buah pepaya (Carica papaya L.). Bul. Teknologi Pascapanen Pertanian 7:98-103.

Tarigan, N.Y.S., I.M.S. Utama, P.K.D. Kencana. 2016. Mempertahankan mutu buah tomat segar dengan pelapisan minyak nabati. J. Biosistem Teknik Pertanian 4:1-9

Taris, M.L., W.D. Widodo, K. Suketi. 2015. Kriteria kemasakan buah pepaya (Carica papaya L.) IPB Callina dari beberapa umur panen. J. Hort. Indonesia 6:172-176.

Tirkey, B., U.S. Pal, L.M. Bal, N.R. Sahoo, C.K. Bakhara, M.K. Panda. 2014. Evaluation of physico-chemical changes of fresh-cut unripe papaya during storage. J. Elsevier 190-197.

Wilia, W., Widodo, S. Wiyono. 2012. Potensi khamir untuk mengendalikan penyakit antraknosa (Colletotrichum acutatum L.) pada tanaman cabai. J. Bioplantae 1:291-298.

Wiyono, S., S. Manuwoto. 2008. Penyakit Antraknosa pada Pepaya dan Potensi Pengendaliannya. Pusat Kajian Buah Tropika, LPPM-IPB, ID.

Workneh, T.S., M. Azene, S.Z. Tesfay. 2012. A review on the integrated agrotechnology of papaya. Afr. J. Biotech. 11:15098-15110.

Yunita, R., R. Poerwanto, S. Wiyono. 2018. Analisis karakteristik kimia buah mangga varietas gedong dengan input teknologi pencucian dan penyimpanan. J. Hexagro. 2:5-10.

Zheng, M., S. Jingying, S. Jian, W. Qingguo, L. Yanhua. 2013. Antimicrobial effects of volatiles produced by two antagonistic Bacillus strains on the Anthracnose pathogen in postharvest mangos. Biol. Control. 65:200-220. 